\title{
Marianne Christensen, La industria ósea de los cazadores recolectores: el caso de los nómadas marinos de Patagonia y Tierra del Fuego
}

Punta Arenas, Universidad de Magallanes, Col. Poblamiento Humano, 2017

\section{Luis Alberto Borrero}

\section{OpenEdition \\ Journals}

\section{Electronic version}

URL: http://journals.openedition.org/artefact/1665

DOI: 10.4000/artefact.1665

ISSN: 2606-9245

Publisher:

Association Artefact. Techniques histoire et sciences humaines, Presses universitaires du Midi

\section{Printed version}

Date of publication: 30 May 2018

Number of pages: $276-277$

ISBN: 978-2-7535-7494-6

ISSN: 2273-0753

Electronic reference

Luis Alberto Borrero, «Marianne Christensen, La industria ósea de los cazadores recolectores: el caso de los nómadas marinos de Patagonia y Tierra del Fuego », Artefact [Online], 7 | 2017, Online since 14

February 2019, connection on 23 September 2020. URL : http://journals.openedition.org/artefact/

1665 ; DOI : https://doi.org/10.4000/artefact.1665

This text was automatically generated on 23 September 2020.

\section{cc)}

Artefact, Techniques, histoire et sciences humaines est mise à disposition selon les termes de la Licence Creative Commons Attribution - Pas d'Utilisation Commerciale - Pas de Modification 4.0 International. 


\title{
Marianne Christensen, La industria ósea de los cazadores recolectores: el caso de los nómadas marinos de Patagonia y Tierra del Fuego
}

Punta Arenas, Universidad de Magallanes, Col. Poblamiento Humano, 2017

\author{
Luis Alberto Borrero
}

\section{REFERENCES}

Marianne Christensen, La industria ósea de los cazadores recolectores: el caso de los nómadas marinos de Patagonia y Tierra del Fuego, Punta Arenas, Universidad de Magallanes, Col. Poblamiento Humano, 2017, 308 p.

1 Marianne Christensen produced a well-researched and necessary book, not only because it synthesizes the evidence for the use of animal hard materials like bones, claws or shells to fabricate tools in Patagonia and Tierra del Fuego, but also because it presents a methodology specifically designed to deal with those materials. This methodology should also be useful for anyone interested in the study of bone tools from other regions of the world. The book is superbly illustrated, a fact that helps to make it a basic reference for researchers interested in bone tools or hunter-gatherer adaptations. The necessity of this book length treatment of bone tools derives not only from their quantitative importance in the archaeological assemblages, but also from their capacity to inform about the mobility and other activities of the prehistoric inhabitants of Patagonia and Tierra del Fuego. Dominique Legoupil affirms in the prologue that bone technology already achieved the state of an independent discipline, and this book constitutes the best confirmation of that comment. 
2 The book is divided in three parts. The first concerns the history, problems and perspectives related with the study of bone tools. The history of research is fascinating because it is a realization of the increasing acknowledgment of the importance of bone tools to understand human adaptations. The role of taphonomic and experimental studies is highlighted and exemplified with convincing examples, many resulting from the work of the author at University Paris 1-Panthéon-Sorbonne.

3 The second part of the book presents detailed ethnographic and archaeological information about Patagonian hunter-gatherers, particularly those inhabiting the western archipelagos, where the majority of the bone tools were recorded. Effectively, bone was one of the more widespread available raw materials for seafaring nomads inhabiting those archipelagos, and accordingly it was intensively used. Anyway, the role and significance of bone tools for terrestrial hunter-gatherers from the Patagonian steppes is also presented and discussed in detail. The use of ethnographic sources is at the base of discussions about the function of bone tools, always combined with actualistic research.

4 Finally, the third part is dedicated to the presentation of the bone tools of Patagonia and Tierra del Fuego themselves, their description, the techniques used for their construction and the ways in which they were used. With few exceptions, bone tools were confined for years to simple descriptions and crude listings, without major consideration for the availability of raw materials, alternative techniques used in their construction or their importance for the functioning of hunter-gatherer adaptations. That debt is fully paid with this book where bone tools receive the importance they deserve and are used to enhance our understanding of general hunter-gatherer adaptations. The use of detailed knowledge of the different classes of available bones from a variety of animals is evident when the basic criteria used to select materials for the construction of different tools-their morphology, size, resistance and other properties-are presented and discussed by Christensen. Importantly, as a result of the clever combination of good descriptions and well-designed experiments the book explores the full potential of bone tools as markers of successful human adaptations along thousands of years. In this way this volume goes well beyond the presentation of the state of the art concerning bone tools, to become a basic reference for anyone interested in the history of human occupations of the southern extreme of the Americas.

\section{AUTHOR}

\section{LUIS ALBERTO BORRERO}

Conicet-Imhicihu, Argentina 